\title{
A PACAP-38 citoprotektív és antiinflammatórikus hatásának vizsgálata vékonybél-autotranszplantációs modellben
}

\section{Examination of cytoprotective and anti-inflammatory effect of PACAP-38 on small bowel autotransplantation}

\author{
NEDVIG KLÁRA ${ }^{1}$, SZABÓ GYÖRGYI ${ }^{2}$, CSUKÁS DOMOKOS ${ }^{2}$, SÁNDOR JÓZSEF ${ }^{2}$, NÉMETH JÓZSEF $^{3}$, \\ KOvÁcs KRISZTINA ${ }^{4}$, REglŐdi DÓRA ${ }^{5}$, KEMÉNY ÁGNES ${ }^{6}$, WÉBER GYÖRGY ${ }^{2}$, FERENCZ ANDREA $^{2, @ ~}$ \\ ${ }^{1}$ Zala Megyei Kórház, Általános Sebészeti és Érsebészeti Osztály, Zalaegerszeg (igazgató: Prof. Dr. Vattay Péter) \\ ${ }^{2}$ Semmelweis Egyetem, Kísérletes és Sebészeti Mütéttani Intézet, Budapest (igazgató: Prof. Dr. Wéber György) \\ ${ }^{3}$ Debreceni Egyetem, Farmakológiai és Farmakoterápiás Intézet, Debrecen (igazgató: Prof. Dr. Szilvássy Zoltán) \\ ${ }^{4}$ Pécsi Tudományegyetem, Biokémiai és Orvosi Kémiai Intézet, Pécs (igazgató: Prof. Dr. Sümegi Balázs) \\ ${ }^{5}$ Pécsi Tudományegyetem, Anatómiai Intézet, Pécs (igazgató: Prof. Dr. Reglődi Dóra); MTA „Lendület PACAP Kutatócsoport” \\ ${ }^{6}$ Pécsi Tudományegyetem, Farmakológiai és Farmakoterápiás Intézet, Pécs (igazgató: Prof. Dr. Pintér Erika)
}

\begin{abstract}
Bevezetés: A vékonybél ischaemia-reperfusióval szembeni fokozott érzékenysége a szerv transzplantációjakor is jelen lévő probléma. Ismert a hypophysis adenilát-cikláz aktiváló polipeptid (PACAP) sejtvédő hatása. Munkánkban azt vizsgáltuk, hogy PACAP-38-at tartalmazó University of Wisconsin (UW) oldatban történő konzerválás hogyan befolyásolja a szöveti PACAP- és citokinszinteket. Anyag és módszer: Wistar-patkányokon $(n=56)$ vékonybélautotranszplantációt végeztünk. A graftokat $4{ }^{\circ} \mathrm{C}$-os UW oldatban tároltuk 1 (I. csoport), 3 (II.) és 6 órán (III.), illetve $100 \mu \mathrm{g}$ PACAP-38-at tartalmazó UW oldatban 1 (IV.), 3 (V.) és 6 órán (VI.) át. A reperfusio 3 óra volt. Bélmintákból a PACAP-38- és PACAP-27-szinteket radioimmunassayjel határoztuk meg, míg a citokinexpressiót kemilumineszcens módszerrel és Luminex Multiplex Immunoassayjel mértük. Eredmények: A szöveti PACAP-38-szint a kontrollhoz $(57,32 \pm 3,5 \mathrm{fmol} / \mathrm{mg})$ képest a konzerválás idejével csökkent, és 6 óra után szignifikáns volt (III.: 32,6 6 3,9 fmol/mg, $p<0,05)$, míg a IV-VI. csoportoknál szignifikánsan nőtt. A PACAP-27 szöveti értéke is hasonló tendenciával változott. Az sICAM-1, L-selectin és a metalloproteáz-1 szöveti inhibitorának emelkedett expressióját mértük a III. csoportban, és jelentős csökkenés volt a VI. csoportban. Következtetés: UW oldathoz adott PACAP-38 növelte a szöveti PACAP-38- és PACAP-27-szinteket, és csökkentette a citokinexpressiót. Mindez a PACAP-38 citoprotektív és anti-inflammatórikus hatását jelzi bél-autotranszplantációs modellben.
\end{abstract}

Támogatta: OTKA (PD77474, 104984, CNK78480), MTA Bolyai-ösztöndíj és Lendület program.

Kulcsszavak: vékonybél, transzplantáció, PACAP-38, PACAP-27, citokinexpressio

Introduction: The small intestine is one of the most sensitive organs to ischemia-reperfusion injury during transplantation. Cytoprotective effect of pituitary adenylate cyclase-activating polypeptide (PACAP) is well known. The aim of our study was to measure changes of PACAP-38-like immunoreactivities and cytokine levels in intestinal grafts stored PACAP-38 containing preservation solution. Material and methods: Small-bowel autotransplantation was performed on male Wistar rats $(n=56)$. Grafts were stored in University of Wisconsin (UW) solution at $4{ }^{\circ} \mathrm{C}$ for 1 (GI), 3 (GII), and 6 hours (GIII); and in PACAP-38 containing UW solution for 1 (GIV), 3 (GV), and 6 hours (GVI). Reperfusion lasted 3 hours in each group. Intestinal PACAP-38 immunoreactivities were measured by radioimmunoassay. To measure cytokine from tissue homogenates we used rat cytokine array and Luminex Multiplex Immunoassay. Results: Levels of PACAP-38-like and PACAP-27-like immunoreactivities decreased by preservation time compared to control. This decrease was significant following 6 hours cold storage $(p<0.05)$. Values remained significantly higher in grafts stored in PACAP-38 containing UW. Expressions of sICAM-1, L-selectin, tissue inhibitor of metalloproteinase-1 were increased in GIII and were decreased in GVI. Conclusion: PACAP-38 increased tissue levels of PACAP-38 and PACAP-27, and decreased cytokine expression. This indicates that PACAP-38 has anti-inflammatory and cytoprotective effects in intestinal autotransplantation model.

Supported by Grant OTKA (PD77474, 104984, CNK78480), Bolyai Scholarship and "Lendület" program of the Hungarian Academy of Sciences.

Keywords: small bowel, transplantation, PACAP-38, cytokine expression

Beérkezett: 2013. szeptember 2.; elfogadva: 2013. szeptember 5.

@ Levelezési cím/Corr. address: Dr. Ferencz Andrea, Semmelweis Egyetem, Kísérletes és Sebészeti Műtéttani Intézet, 1089 Budapest, Nagyvárad tér 4., Tel.: +36 1459 1500/56575, Fax: +36 1459 1500/56574, E-mail: andrea.ferencz@gmail.com 


\section{Bevezetés}

A vékonybél fokozottan érzékeny a szöveti ischaemiás/ reperfusiós (I/R) károsodásokra, amivel transzplantációja során is számolnunk kell. Kísérletes és klinikai eredmények igazolták, hogy transzplantációkor a konzerválás (hideg ischaemia) és a reperfusio mind rövid, mind hoszszú távon káros hatású, növeli az acut kilökődések számát, vagy krónikus allograft-funkciózavart okoz. ${ }^{1-2} \mathrm{~A}$ jelenleg „standardként" használt University of Wisconsin (UW) konzerváló oldatot főként vese és máj tárolására fejlesztették ki. A többi szervvel kapott jó eredmények ellenére a bélgraftok tárolására ez az oldat nem „optimális". 3-4 Folyamatos kutatások folynak a forgalomban lévő oldatok módosítása (új összetevők, magasabb energia- és tápanyagtartalom), illetve új oldatok kifejlesztése terén. $^{5-7}$

A hypophysis adenilát-cikláz aktiváló polipeptid (Pituitary adenylate-cyclase activating polypeptide, PACAP) az evolúció során jól konzervált, széles hatásspektrumú neuropeptid, amely hat az endokrin mirigyekre, a cardiovascularis és légzőrendszerre, valamint az emésztőtraktusra is. A polipeptidnek két formája van, a 38 aminosavat tartalmazó PACAP-38 és a 27 aminosavból álló PACAP-27. ${ }^{8}$ Mint „brain-gut” peptidek az emésztőrendszer teljes hosszában megtalálhatóak, immunreaktivitásuk a sejttestekben és az idegvégződésekben mutatható ki, főként a jejunum és az ileum területén. ${ }^{9}$ Fokozott affinitással kötődnek a PAC1 és a VIP-del (vasoactiv intestinal peptid) közös VPAC1 és VPAC2 receptorokhoz. ${ }^{8-9}$ Mindhárom receptoruk megtalálható a mucosában, a myentericus neuronokban, neuroendokrin és érendothelsejteken, valamint a simaizomsejteken. ${ }^{10-11}$

A PACAP-38 antiapoptotikus, antiinflammatórikus és antioxidáns protektív hatása számos in vitro és in vivo kísérletben igazolódott. ${ }^{12-15}$ Pontosan még nincs tisztázva, hogy milyen mechanizmusokon keresztül hat, de az igen, hogy a bélszöveti I/R-s károsodás a béltraktusban citokinfelszabadulást eredményez. ${ }^{16}$ Számos gyulladásos modellben leírták, hogy a PACAP antiinflammatórikus hatása részben a citokinek és kemokinek termelődésének gátlása révén érvényesül. ${ }^{15,17-19}$ Célunk vékonybél-autotranszplantáció során PACAP-38-at tartalmazó UW oldatban történő konzerválást követően a szöveti PACAP-38 és PACAP-27 immunreaktivitásának, valamint a citokinszinteknek a kimutatása volt.

\section{Anyag és módszer}

Kísérleteinkhez felnőtt hím Wistar-patkányokat ( $n=56$, $n=8$ /csoport) használtunk. Az altatáshoz intramuscularisan ketamin-hidrokloridot (75 mg/testsúly-kg) és diazepamot (75 mg/testsúly-kg) adtunk. A vizsgálatokat a Pécsi Tudományegyetem Munkahelyi Állatkísérleti Bizottsága engedélyében (BA02/2000-9/2008) megadott módon végeztük el.

\section{Vékonybél-autotranszplantációs modell}

$\mathrm{Az}$, ,S” (Sham) csoportba a csak median laparotomián átesett, áloperált állatok kerültek. Az I-VI. csoportokban Na-heparin $(0,2 \mathrm{U} / \mathrm{g})$ adása mellett minden esetben a colon descendensig történő vékonybél-resectio történt, majd a bél lumenét fiziológiás sóoldattal mostuk át. A graftok perfusiója az arteria mesenterica superioron keresztül valósult meg. Majd $100 \mathrm{ml} 4{ }^{\circ} \mathrm{C}$-os UW oldatban tároltuk (ViaSpan, Dupont Pharma, Bad Hamburg, Németország) 1 órán (I. csoport), 3 órán (II. csoport) és 6 órán keresztül (III. csoport). A további graftokat $100 \mu \mathrm{g}$ PACAP-38-at tartalmazó $100 \mathrm{ml}$ UW oldatban 1 órán (IV. csoport), 3 órán (V. csoport) és 6 órán keresztül (VI. csoport) konzerváltuk. Ezt követően end-to-end érvarrattal állítottuk helyre a mesenterialis erek folytonosságát. A reperfusio minden esetben 3 órán át tartott. A laparotomia után (kontroll, K) és a reperfusio végén szövetmintákat vettünk.

\section{Radioimmunoassay}

A bélszövetből származó mintákat (600 mg) jéghideg vízben homogenizáltuk, majd 12 000-es fordulatszámon 30 percig $4{ }^{\circ} \mathrm{C}$-os hőmérsékleten centrifugáltuk. Ezután a felülúszót a PACAP-38-szerü és PACAP-27-szerü immunreakciók vizsgálata céljából RIA analízisnek vetettük alá, ahogy azt korábban leírtuk. ${ }^{20}$ A PACAP-38 antiszérumát 88111-3-mal, a PACAP-27 antiszérumát 88123-mal rövidítettük. Jelölt anyagként 125-ös jódizotóppal jelölt juhból származó PACAP24-38-at és PACAP-27-et használtunk (csövenként 5000 cpm-et). A standardjaink juhból származó PACAP-38 és PACAP-27 voltak (0-1000 fmol/ml). A vizsgálatot $0,1 \mathrm{M}$ NaCl-ot, $0,05 \%$ nátrium-azidot és 0,25\% marha-szérumalbumint tartalmazó 7,4-es pH-jú 0,05 M-os $1 \mathrm{ml}$ térfogatú foszfátpufferben végeztük. A vizsgálati elegy $100 \mu \mathrm{l}$ antiszérumot (a 88111-3 jelüböl 1:10 000 hígítást, a 88123 jelüből 1:45 000 hígítást), 100 $\mu 1$ jelölt anyagot és $100 \mu \mathrm{l}$ standardot vagy ismeretlen mintát tartalmazó polipropilén csövekbe került. 48-72 órát követő $4{ }^{\circ} \mathrm{C}$-on történő inkubáció után az (antiszérumból származó) antitesteket megkötő peptideket $100 \mu$ l szeparáló oldat segítségével elkülönítettük azoktól a peptidektől, amelyek nem kötöttek antitestet. A szeparáló oldat összetétele: $10 \mathrm{~g}$ aktív szén, $1 \mathrm{~g}$ dextrán és $0,2 \mathrm{~g}$ közönséges zsírmentes tejpor $100 \mathrm{ml}$ desztillált vízben oldva. $4{ }^{\circ} \mathrm{C}$-on 20 percig 3000-es fordulaton való centrifugálást követően a cső tartalmának felülúszóját óvatosan elöntöttük (= dekantáltuk), és a csőben maradó csapadék radioaktivitását gamma-számlálóval mértük. Az ismeretlen minta PACAP38-, illetve PACAP-27-tartalmát kalibrációs görbe segítségével határoztuk meg. A PACAP-38-szerü és PACAP-27szerü kötődés arányát femtomol/mg szövetértékben adtuk meg. 


\section{A citokinaktivitás mérése}

\section{Citokin Array}

A bélszövet citokintartalmának kemilumineszcens vizsgálatát a korábban leírtak szerint végeztük. ${ }^{13}$ Röviden, a szöveti homogenizátum méréséhez patkánycitokinkittet használtunk (Panel A Array kit, R\&D Systems). A bélszövetet proteáz inhibitor tartalmú PBS pufferben homogenizáltuk, Triton X-100-at adtunk hozzá, majd $-80{ }^{\circ} \mathrm{C}$-on tároltuk a felhasználásig. A mintákhoz antitestelegyet adtunk, majd 1 órán át szobahőmérsékleten inkubáltuk őket. Háromszori pufferes mosás után tormaperoxidáz-konjugált Streptavidint adtunk a mintákhoz, és kemilumineszcens mérés (Amersham Biosciences, Hungary) után rtg-filmre rögzítettük az eredményeket.

\section{Luminex Multiplex Immunassay}

A korábban leírtak alapján a bélszövetben három „host” marker (szolúbilis intercellularis adhaesiós molekula-1: sICAM-1; L-szelektin; tissue inhibitor of metalloproteináz-1: TIMP-1) szintjét határoztuk meg Flurokine MAP Rat Base kit (R\&D Systems) segítségével, a gyártó instrukciói alapján. ${ }^{21} \mathrm{Az}$ eredményeket pg/g nedvesszövet-értékben adtuk meg.

\section{Statisztika}

$\mathrm{Az}$ eredmények értékelésekor átlagot és standard errort számoltunk. Az adatokat ANOVA varianciaanalízissel dolgoztuk fel. A szignifikancia szintje $p<0,05$ volt. Az adatok kiértékeléshez a MicroCal Origin (6.0) programot (Microcal Software, USA) alkalmaztuk.

\section{Eredmények}

\section{Radioimmunassay}

A szöveti PACAP-38-szerü immunreaktivitás 57,32 \pm $3,5 \mathrm{fmol} / \mathrm{mg}$ volt a kontrollmintákban, és $55,1 \pm$ $2,5 \mathrm{fmol} / \mathrm{mg}$ az áloperált csoportban. Értéke 1 órás hideg konzerválást követően $50,4 \pm 3,5 \mathrm{fmol} / \mathrm{mg}$-ra (I. csoport), 3 óra után $40,1 \pm 5,5 \mathrm{fmol} / \mathrm{mg}$-ra csökkent (II. csoport). Ez a változás a 6 órás konzerválás végére (III. csoport: 32,6 \pm 3,0 fmol/mg; $p<0,05)$ szignifikáns volt. PACAP-38-at tartalmazó UW oldatban történő tárolást követően szignifikánsan magasabb szinteket mértünk (IV-VI. csoport). Értéke a IV. csoportban 65,2 \pm 3,4 fmol/mg, az V. csoportban 55,2 $\pm 4,2 \mathrm{fmol} / \mathrm{mg}$, míg a 6 órás csoportban 48,9 $\pm 3,2 \mathrm{fmol} / \mathrm{mg}$ volt (1. ábra).

A szöveti PACAP-27-szerű immunreaktivitás a hideg konzerválás és az autotranszplantáció során csökken a kontroll- (4,2 $\pm 0,2$ fmol/mg) mintákhoz képest. Ez a csökkenés szignifikáns volt mind az 1 órás (I. csoport: $2 \pm$ $0,2 \mathrm{fmol} / \mathrm{mg} ; p<0,05$ ), mind a 3 órás (II. csoport: 1,6 \pm
$0,3 \mathrm{fmol} / \mathrm{mg} ; p<0,05$ ), mind a 6 órás (III. csoport: $0,9 \pm$ $0,2 \mathrm{fmol} / \mathrm{mg} ; p<0,01)$ mintáknál is. PACAP-38-at is tartalmazó UW oldatban történő tárolást követően értéke szignifikánsan magasabb volt a csak UW-ban tárolt mintákhoz képest (IV. csoport: 3,5 $\pm 0,3 \mathrm{fmol} / \mathrm{mg}$; V. csoport: 3,0 \pm $0,2 \mathrm{fmol} / \mathrm{mg}$; VI. csoport: $2,6 \pm 0,15 \mathrm{fmol} / \mathrm{mg} ; p<0,05)$ (2. ábra).

\section{Citokinmérési eredmények}

A kemiluminenszcens vizsgálatok igazolták, hogy a citokinek közül a szolúbilis intercellularis adhaesiós molekula (sICAM-1, CD54) (3. ábra, 1) és az L-szelektin (CD62L/ LECAM-1) (3. ábra, 2) normál aktivitása volt detektálható a kontrollbélszövetben. A III. csoportban expressiójuk nem változott 6 órás UW oldatban történő konzerválás és az azt

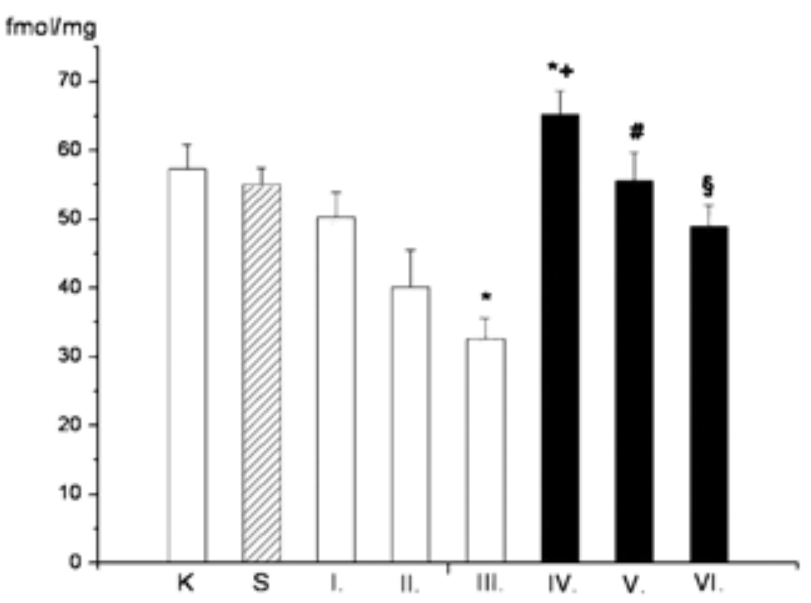

1. ábra. A PACAP-38 immunreaktivitásának szintje autotranszplantált vékonybélszövetben (K: kontroll, $\mathrm{S}$ : áloperált; Mean $\pm \mathrm{SE} ;{ }^{*} p<0,05$ vs. kontroll; $+p<0,05$ vs. I. csoport; $\# p<0,05$ vs. II. csoport; $\S p<0,05$ vs. III. csoport)

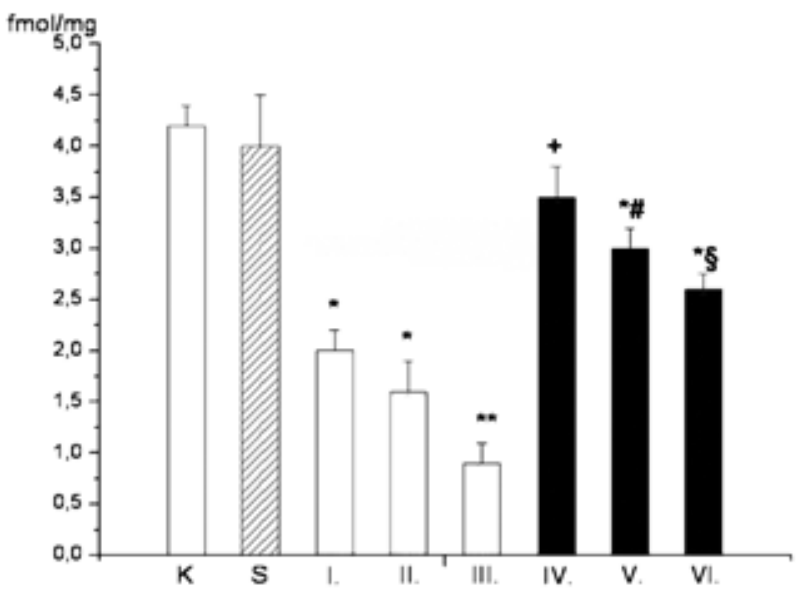

2. ábra. A PACAP-27 immunreaktivitásának szintje autotranszplantált vékonybélszövetben (K: kontroll, $\mathrm{S}$ : áloperált; Mean $\pm \mathrm{SE}$; $p<0,05$ vs. kontroll; ** $p<0,01$ vs. kontroll; $+p<0,05$ vs. I. csoport; \# $p<0,05$ vs. II. csoport; $\S p<0,05$ vs. III. csoport) 


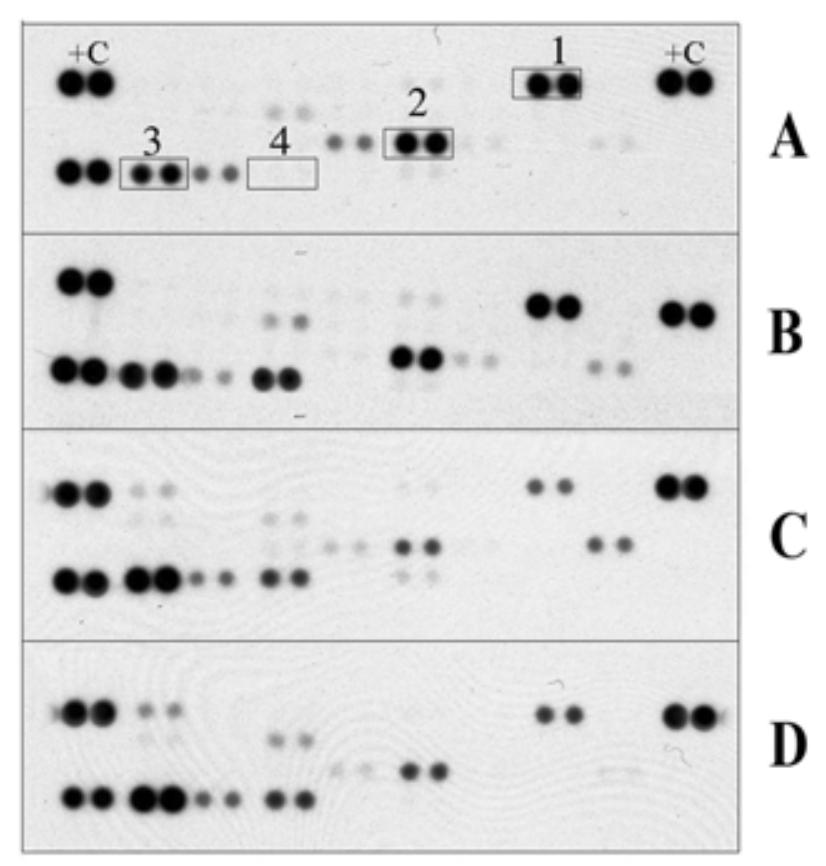

3. ábra. A bélszövet citokinexpressiójának vizsgálata kemilumineszcens módszerrel. Különböző citokinek jelenléte látható a kontroll (a), 6 órás hideg UW oldatban történő konzerválás (b), 6 órás hideg konzerválás PACAP-38-at tartalmazó UW oldatban (c) és az azt követő reperfusio (d) során. Jelentős változás figyelhető meg az sICAM-1 (1), az L-szelektin (2) és a TIMP-1 (4) expressiójában. A RANTES- (CCL5) szintek (3) minden csoportban emelkedettek voltak (+K: pozitív kontroll). A többi citokinnél (bal felső saroktól indulva: CINC-1, CINC-2alpha/beta, CINC-3, GM-CSF, IFN-gamma, IL-1alpha，IL-1beta，IL-1ra，IL-2，IL-3，IL-4，IL-6，IL-10, IL-13, IL-17, IP-10, LIX, MIG, MIP-1alpha, TNF-alpha és VEGF) nem volt változás

követő reperfusiós periódus végére. A VI. csoportban mind a 6 órás PACAP-38-at tartalmazó UW oldatban történő konzerválás, mind az azt követő 3 órás reperfusio jelentős citokinaktivitás-csökkenést okozott. A RANTES (CCL5) (3. ábra, 3) szintek minden csoportban megemelkedtek. A kontrollmintákban a mátrix-metalloproteináz szöveti inhibitorának (TIMP-1) aktivitása (3. ábra, 4) nem volt mérhető. Jelentős aktivitást mértünk a III. csoportban a 6 órás PACAP-38 nélküli UW oldatban való konzerválást követően. A VI. csoportban a PACAP-38-at tartalmazó hideg konzerválás csökkentette ezen aktivitások szintjét.

Az előbbi méréseket a Luminex Immunoassayjel kapott eredmények is megerősítették (4.a-c ábra). Az sICAM és az L-szelektin expressiója hasonló a kontroll- (4.a-b ábra, A oszlop) és az ischaemiás csoportokban (4.a-b ábra, B oszlop), míg mindkét esetben szignifikáns csökkenés figyelhető meg a PACAP-38-cal tárolt graftoknál (4. $a-b$ áb$r a$, C és D oszlop). A TIMP expressiója a kimutatási határon volt a kontrollmintákban (4.c ábra, A oszlop), és jelentős emelkedés volt hideg ischaemia után (4.c ábra, B oszlop). Az emelkedett TIMP-szinteket mérsékelte a PACAP38-at tartalmazó konzerválás (4.c ábra, C és D oszlop).

\section{Megbeszélés}

Jelen kutatásunkban kísérletes vékonybél-autotranszplantáció során vizsgáltuk a bélszövet PACAP-38- és PACAP27-szintjét, valamint a szöveti citokinexpressiót, a szervkonzerváláshoz PACAP-38-at tartalmazó UW oldatot használva.

Az intenzív kutatásoknak köszönhetően az utóbbi években egyre több vékonybél-transzplantáció történik a világon, azonban a graftok és a betegek túlélését a klinikai gyakorlatban ma is számos probléma befolyásolja. A konzerváló oldat alapvető szerepet játszik a hideg ischaemia és az azt követő reperfusio során fellépő szövetkárosodás csökkentésében. A klinikai rutin szerint jelenleg UW oldatot használnak a bélgraftok tárolására. Ez az oldat máj és vese konzerválása esetén számos előnnyel bír, ugyanakkor a vékonybél tárolásához nem optimális. ${ }^{4,22}$ Számos kutatás folyik a kereskedelemben kapható oldatok összetételének módosítása, illetve új oldatok kifejlesztése terén.

Vizsgálatunkban kimutattuk, hogy a bélszövet PACAP38-szerü és PACAP-27-szerü immunreaktivitása a konzerválási idő előrehaladtával 1 és 3 órás hideg tárolást követő-
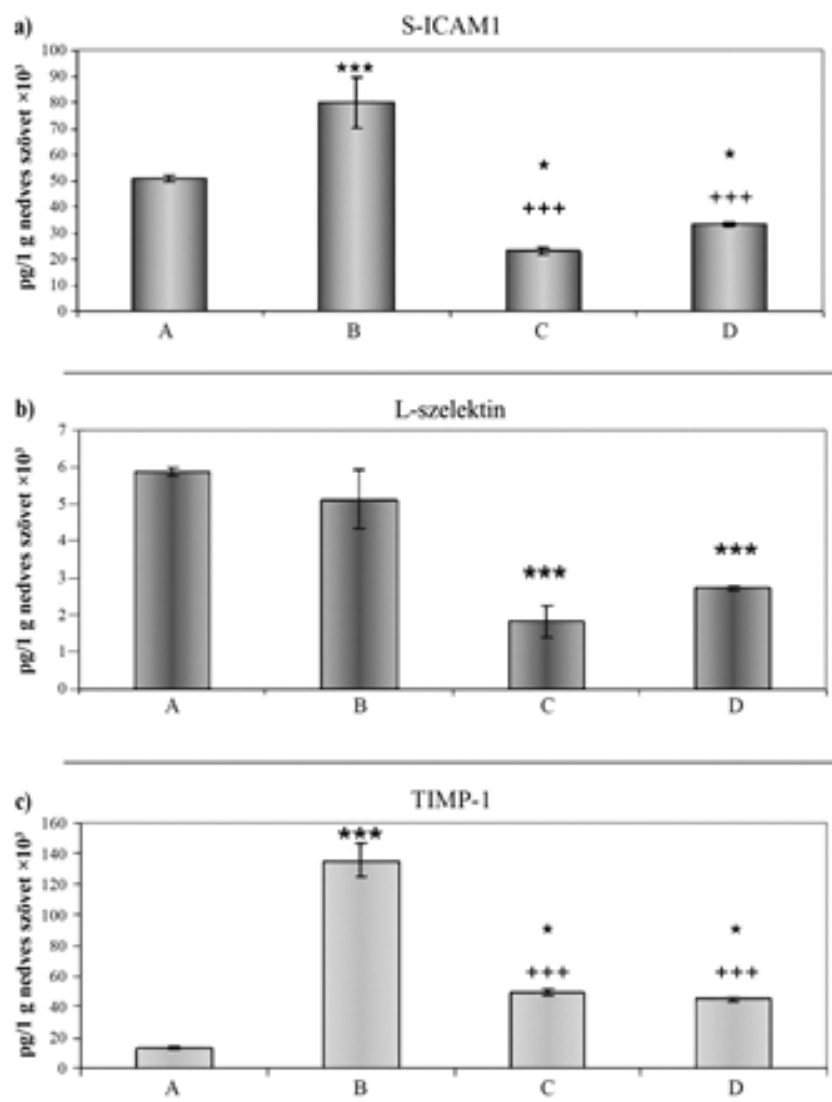

4. ábra. A bélszövet citokinexpressiójának vizsgálata immunassay módszerrel. Az sICAM-1, az L-szelektin és a TIMP-1 expressiójában bekövetkező változások láthatóak a kontroll (A), 6 órás hideg UW oldatban történő konzerválás (B), 6 órás hideg konzerválás PACAP-38-at tartalmazó UW oldatban (C) és az azt követő reperfusio (D) alatt (Mean $\pm \mathrm{SE}$; $p<0,05$ vs. A; $* * * p<0,01$ vs. $\mathrm{A} ;+++p<0,001$ vs. $\mathrm{B})$ 
en csökkent. Ez a csökkenés 6 órás hideg ischaemia után szignifikáns volt. Korábbi meleg I/R-s vékonybélmodellben végzett kutatásaink hasonló eredményeket mutattak az endogén PACAP-38 szintjének változása tekintetében. ${ }^{12} \mathrm{~A}$ hideg ischaemiát követő PACAP-38-szint csökkenését okozhatja mind az ischaemiás sejtek fokozott PACAP-38felvétele, mind a PACAP-38 szintézisének csökkenése, mind pedig a sejtkárosodás miatti fokozott PACAP-lebomlás. Hasonló megfigyelést tettek kísérletes fekélymodellben is, ahol a PACAP immunreaktivitásának acut csökkenését figyelték meg. ${ }^{23}$ A PACAP-38- és PACAP-27-szintek szignifikánsan magasabbak voltak azokban a graftokban, amelyeket PACAP-38-tartalmú UW oldatban tároltunk. Érdekes módon 1 órás konzerválást követően a PACAP-38 szintje a kontrollértékek fölé emelkedett. 3 és 6 órás, PACAP-38-at tartalmazó UW oldatban történő konzerválás hatására a bélsejt-homogenizátumban szignifikánsan megnőtt a PACAP-38- és PACAP-27-szint. A reperfusiós időszak végén észlelt emelkedett értékek kialakulásáért felelös mechanizmust pontosan nem ismerjük. Ezt okozhatja az endothelsejtekben a hypoxia következtében csökkent adenilát-cikláz-aktivitás miatt kialakult alacsonyabb intracellularis cAMP-szint. ${ }^{24} \mathrm{Ez}$ a feltételezés in vivo vékonybél-prezervációs vizsgálatok során is megerősítést nyert. Az említett mechanizmusok közül a cellularis cAMP-jelátvitel játszhatja a fő szerepet az ischaemiás bél integritásának megőrzésében. ${ }^{25}$ A legújabb tanulmányok megerősítették, hogy a PACAP-38 hatására a cAMP-szint megemelkedik, ami megóvja a bélszövetet az I/R okozta károsodástól. $^{26}$ Továbbá kimutatták, hogy az alapvetően extrinsic denervatióval járó vékonybél-transzplantáció során a PACAP-38-szint a gyomorban csökken, de a bélben nem. Mindezek alapján feltételezhető, hogy a bél PACAP38-tartalmú idegrostjainak kettős - intrinsic és extrinsic eredete van. ${ }^{9}$ A másik lehetséges magyarázat, hogy a konzerváló oldathoz adott, külsőleg bevitt PACAP specifikus receptoraihoz hozzákötődve fejti ki antioxidáns és protektív hatását a bélben. ${ }^{7,12}$

A bélszövet károsodásáért elsősorban az I/R során keletkező gyulladáskeltő mediátorok, közöttük a citokinek is felelősek. Az indukált gyulladásos kaszkád aktiválhatja a leukocytákat és az endothelsejteket, ami végül szöveti gyulladáshoz, többszervi elégtelenséghez és halálhoz vezethet. I/R-t követően vékonybél-transzplantáció során a bél citokintermelő szervvé válik, fenyegetve ezáltal a graft és a beteg túlélését. ${ }^{27}$

Jelen vizsgálatunkban azt találtuk, hogy az sICAM-1 és az L-szelektin expressiója jelen volt a kontrollbélszövetben is, és szabályos aktiválódást mutatott 6 órás, hideg UW oldatban való konzerválás és azt követő reperfusio során. Ezzel szemben a 6 órás, PACAP-38-tartalmú UW oldatban való tárolás jelentősen csökkentette a citokinek aktivációját. A sICAM-1 és az L-szelektin fokozott expressiója vese I/R-t követően is megfigyelhető volt, ugyanakkor ott a PACAPkezelt csoportokban csökkenés volt kimutatható. ${ }^{13,15} \mathrm{~A}$ citokinek közé tartozó adhaesiós molekulák részt vesznek a leukocyták, a vérlemezkék, a T-sejtek és az endothelsejtek közötti intercellularis kommunikációban, beindítva ezzel a microvascularis sérülést és a reperfusiós károsodást. ${ }^{28} \mathrm{~A}$ RANTES (CCL5) nem konstitutívan termelődő kemokin, csupán gyulladás során expressálódik. Modellünkben a CCL5-szint minden csoportban emelkedett volt, ugyanakkor a PACAP-kezelt csoportokban enyhe csökkenés volt megfigyelhető. Gyulladásos folyamatokban a mátrixmetalloproteináz-9 (MMP-9) és endogén inhibitorának (TIMP-1) transzkripciója a proinflammatórikus mediátorok hatására indukálódik. Kísérletünkben a TIMP-1 erőteljes aktivációja volt kimutatható PACAP-38 nélküli UW oldatban való 6 órás tárolást követően. PACAP-38 tartalmú oldatban történő konzerválás csökkentette az aktivációt. A PACAP gyulladásgátló hatása részben a citokin- és kemokintermelésre történő gátló hatása révén érvényesül. ${ }^{13,15,17}$

Összefoglalva elmondhatjuk, hogy eredményeink igazolták a PACAP-38 citoprotektív és antiinflammatórikus hatását PACAP-38-at tartalmazó UW oldatban történt vékonybél-konzerválás és -autotranszplantáció során, aminek a jövőben klinikai jelentősége lehet.

\section{Köszönetnyilvánítás}

A szerzők köszönettel tartoznak a Pécsi Tudományegyetem Sebészeti Oktató és Kutató Intézet munkatársainak a kísérletek elvégzéséhez nyújtott segítségért. A kutatást támogatta az OTKA PD77474, 104984, CNK78480, az MTA Bolyai-ösztöndíj és Lendület program.

\section{Irodalomjegyzék}

1 Ferencz A, Nedvig K, Fekecs T, Rácz B, Wéber Gy, Hashimoto H, Baba A, Helyes Z, Reglödi D: Comparison of intestinal cold preservation injury on pituitary adenylate cyclase-activating polypeptide in knockout and wildtype mice. Transplant Proc 2010; 42: 2290-2

2 Linfert D, Chowdhry T, Rabb H: Lymphocytes and ischemia-reperfusion injury. Transplant Rev 2009; 23: 1-10

3 Maathuis MH, Leuvenink HG, Ploeg RJ: Perspectives in organ preservation. Transplantation 2007; 83: 1289-98

4 Roskott AM, Nieuwenhuijs VB, Dijkstra G, Koudstaal $L G$, Leuvenink HG, Ploeg RJ: Small bowel preservation for intestinal transplantation: a review. Transpl Int 2011; 24: 107-31

5 Inuzuka K, Unno N, Yamamoto N, Sagara D, Suzuki M, Nishiyama $M$, Konno $H$ : Effect of hyperbarically oxygenated-perfluorochemical with University of Wisconsin solution on preservation of rat small intestine using an original pressure-resistant portable apparatus. Surgery $2007 ; 142$ : 57-66

6 Wei L, Hata K, Doorschodt BM, Büttner R, Minor T, Tolba $R H$ : Experimental small bowel preservation using Polysol: A new alternative to University of Wisconsin solution, Celsior and histidine-tryptophan-ketoglutarate solution? World J Gastroenterol 2007; 13: 3684-91 
7 Ferencz A, Rácz B, Tamás A, Reglödi D, Lubics A, Németh J, Nedvig K, Kalmár-Nagy K, Horváth OP, Wéber Gy, Röth E: Influence of PACAP on oxidative stress and tissue injury following small bowel autotransplantation. J Mol Neurosci 2009; 37: 168-76

8 Vaudry D, Falluel-Morel A, Bourgault S, Basille M, Basille D, Wurtz O, Fournier A, Chow BK, Hashimoto H, Galas L, Vaudry H: Pituitary adenylate cyclase-activating polypeptide and its receptors: 20 years after the discovery. Pharmacol Rev 2009; 61: 283-357

9 Hannibal J, Ekblad E, Mulder H, Sundler F, Fahrenkrug $J$ : Pituitary adenylate cyclase activating polypeptide (PACAP) in the gastrointestinal tract of the rat: Distribution and effects of capsaicin or denervation. Cell Tissue Res 1998; 291: 65-79

10 Schulz S, Rocken C, Mawrin C, Weise W, Hollt V, Schulz $S$ : Immunocytochemical identification of VPAC1, VPAC2, and PAC1 receptors in normal and neoplastic human tissues with subtype-specific antibodies. Clin Cancer Res 2004; 10: 8235-42

11 Pirone A, Baoan D, Piano I, Santina LD, Baglini A, Lenzi $C$ : Pituitary adenylate cyclise-activating peptide (PACAP) immunoreactivity distribution in the small intestine of the adult New Hampshire chicken. Acta Histochem 2011; 113: 477-83

12 Ferencz A, Kiss P, Wéber Gy, Helyes Zs, Shintani N, Baba A, Reglödi D: Comparison of intestinal warm ischemic injury in PACAP knockout and wild-type mice. J Mol Neurosci 2010; 42: 435-42

13 Horváth G, Márk L, Brubel R, Szakály P, Rácz B, Kiss P, Tamás A, Helyes Zs, Lubics A, Hashimoto H, Baba A, Shintani N, Furjes G, Németh J, Reglodi D: Mice deficient in pituitary adenylate cyclase activating polypeptide display increased sensitivity to renal oxidative stress in vitro. Neurosci Lett 2010; 469: 70-4

14 Rácz B, Gallyas F, Kiss P, Tóth G, Hegyi O, Gasz B, Borsiczky B, Ferencz A, Röth E, Tamás A, Lengvári I, Lubics $A$, Reglödi $D$ : The neuroprotective effects of PACAP in monosodium glutamate-induced retinal lesion involves inhibition of proapoptotic signaling pathways. Regul Pept 2006; 137: 20-6

15 Reglödi D, Kiss P, Szabadfi K, Atlasz T, Gábriel R, Horváth G, Szakály P, Sándor B, Lubics A, László E, Farkas J, Matkovits A, Brubel R, Hashimoto H, Ferencz A, Vincze A, Helyes Zs, Welke L, Lakatos A, Tamás A: PACAP is an endogenous protective factor - insights from PACAP deficient mice. J Mol Neurosci 2012; 48: 482-92

16 Grotz M, Deitch EA, Ding J, Xu D, Huang Q, Regel G: Intestinal cytokine response after gut ischemia. Role of gut barrier failure. Ann Surg 1999; 229: 478-86

17 Delgado M, Genea D: Inhibition of endotoxin-induced macrophage chemokine production by vasoactive intestinal peptide and pituitary adenylate cyclise activating polypeptide in vitro and in vivo. $\mathrm{J}$ Immunol 2001; 167: 966-75
18 Horváth G, Rácz B, Reglödi D, Kovács K, Kiss P, Gallyas F, Bognár Z, Szabó A, Magyarlaki T, László E, Lubics A, Tamás A, Tóth G, Szakály P: Effects of PACAP on mitochondrial apoptotic pathways and cytokine expression in rats subjected to renal ischemia/reperfusion. J Mol Neurosci 2010; 42: 411-8

19 Ohtaki H, Satoh A, Nakamachi T, Yofu S, Dohi K, Mori $H$, Ohara K, Miyamoto K, Hashimoto H, Shintani N, Baba A, Matsunaga M, Shioda $S$ : Regulation of oxidative stress by pituitary adenylate cyclise-activating polypeptide (PACAP) mediated by PACAP receptor. J Mol Neurosci 2010; 42: 397-403

20 Brubel R, Horváth G, Reglödi D, Lubics A, Tamás A, Kiss $P$, László E, Németh J, Márk L, Szakály P: Presence of pituitary adenylate cyclase activating polypeptide and its type I receptor in the rat kidney. Transplant Proc 2011; 43: 1297-9

21 Nedvig K, Wéber Gy, Németh J, Kovács K, Reglödi D, Kemény A, Ferencz A: Changes of PACAP immunoreactivities and cytokine levels after PACAP-38 containing intestinal preservation and autotransplantation. J Mol Neurosci 2012; 48: 788-94

22 Salehi P, Spratlin J, Chong F, Churchill A: Beneficial effects of supplemental buffer and substrate on energy metabolism during small bowel storage. Cryobiology 2004; 48: 245-53

23 Mei $Q$, Sundler $F$ : Changes in pituitary adenylate cyclase activating polypeptide and vasoactive intestinal peptide innervation of rat oxyntic mucosa during ulcer healing. Neuropeptides 1998; 32: 527-35

24 Yan SF, Ogawa S, Stern DM, Pinsky DJ: Hypoxiainduced modulation of endothelial cell properties: Regulation of barrier function and expression on interleukin-6. Kidney Int 1997; 51: 419-25

25 Minor T, Isselhard W: Cellular signal level of cyclic AMP and functional integrity of the small bowel after ischemic preservation: An experimental pilot study in the rat. Eur Surg Res 1998; 30: 144-8

26 Riera M, Torras J, Cruzado JM, Lloberas N, Liron J, Herrero I, Navarro MA, Grinyo JM: The enhancement of endogenous cAMP with pituitary adenylate cyclase activating polypeptide protects rat kidney against ischemia through the modulation of inflammatory response. Transplantation 2001; 72: 1217-23

27 Kostopanagiotou G, Avgerinos ED, Markidou E, Voiniadis $P$, Chondros $C$, Theodoraki K, Smyrniotis V, Arkadopoulos $N$ : Protective effect of NAC preconditioning against ischemia-reperfusion injury in piglet small bowel transplantation: effects on plasma TNF, IL-8, hyaluronic acid, and NO. J Surg Res 2011; 168: 301-5

28 Vollmar B, Menger MD: Intestinal ischemia/reperfusion: microcirculation pathology and functional consequences. Langenbecks Arch Surg 2011; 396: 13-29 